\title{
UPPER TRIASSIC TO LOWER JURASSIC SHALLOW-WATER CARBONATES NORTH OF LAKE SHKODRA (NW ALBANIA, ALBANIAN ALPS ZONE): PART OF THE ADRIATIC CARBONATE PLATFORM BASEMENT
}

\author{
Hans-Jürgen Gawlick ${ }^{1 *}$ \& Felix Schlagintweit ${ }^{2}$
}

Received: 18 November 2018 / Accepted: 06 January 2019 / Published online: 16 January 2019

\begin{abstract}
The palaeogeographic reconstruction of the Adriatic Carbonate Platform and its continuation to the south represents a helpful tool to understand the Mesozoic palaeogeography of the Dinarides-Albanides-Hellenides orogenic system. In the present paper poorly known Upper Triassic to Lower Jurassic (Toarcian) shallow-water carbonates from the Shkodra area in northwest Albania (external Albanides; Albanian Alps zone) were investigated, dated mainly by larger benthic foraminifera. The microfossil associations as well as litho- and microfacies characteristics are equivalent to contemporaneous shallow-water carbonate successions of the Adriatic Carbonate Platform basement to the NW (in the High Karst zone). As a result of our study we clearly see a continuation of the Adriatic Carbonate Platform from the Dinarides to the Albanides. In the area north of Lake Shkodra no Upper Triassic to Lower Jurassic hemipelagic sedimentary rocks, which could be a possible connection between the Budva Unit to the NW and the Cukali Unit to the SW, were detected.
\end{abstract}

Keywords: Upper Triassic, Lower Jurassic, micropalaeontology, microfacies, biostratigraphy, Albanian Alps

\section{INTRODUCTION}

The north Albanian Upper Triassic to Lower Jurassic shallow-water carbonates play a crucial role in palaeogeographic reconstructions of the Adriatic Carbonate Platform system continuation towards the SE. Especially the connection of interfingering deep water basins, the so called Budva Trough in the Dinarides (Petković, 1958) and the Cukali Trough (Albanides; Nopsca, 1929) in the southeastern part of this shallow-water carbonate platform area is discussed controversially (Meco and Aliaj, 2000 for the Albanian Alps with references therein). Several authors connect both by a broad hemipelagic corridor through the southern Albanian Alps zone (e.g., Tari, 2002; Vlahović et al., 2005). According to this model, those transitional basinal sequences should therefore occur in the area of Lake Skhodra. A Lower Jurassic platform-to-basin transitional facies in the Dinarides, for instance, was studied by Črne and Buser (2006) and Črne and Goričan (2008) in the Rumija area south of Lake Skhodra in southern Montenegro, close to the Albanian border and should improve the existence of the Middle Triassic to Late Cretaceous deep-water Budva-Cukali Basin to the west. Other authors instead connect the Budva Trough and the Cukali Trough (= Krasta - Cukali zone - e.g. Meco and Aliaj, 2000; Robertson and Shallo, 2000; Fig. 1) by hemipelagic sediments striking from southeast to northwest south of Lake Skhodra, whereas the Albanian Alps zone should represent a shallow water carbonate areal. Some authors even see independent palaeogeographic domains (Dimitrijević, 1997): the Budva Zone should end in the east around the Albanian border, whereas the Cukali region should be part of the Krasta zone striking to the southeast.

Resulting from the lack of exact stratigraphic data, however, the formation of these hemipelagic basins is dis- cussed controversially as Triassic Troughs (e. g., Meco and Aliaj, 2000; Robertson and Shallo , 2000; Tari, 2002), Jurassic-Cretaceous Troughs (e.g., Goričan, 1994; Vlahović et al., 2005) or polyphase evolution. Furthermore problematic is also the structural interpretation and the reconstruction of the palaeogeographic position without exact knowledge about the age of nappe thrusting, resulting e.g. in the correlation of the Krasta zone with the Cukali zone. According to Beccaluva et al. (1997), the Krasta zone consists of Lower Cretaceous flyschoidal sediments, Upper Cretaceous pelagic limestones and Maastrichtian to Eocene flysch; older sediments are unknown. In contrast, the Cukali zone consists of (Permian-) Triassic to Jurassic deep-water sediments with an overlying Cretaceous-Palaeogene sequence similar to the Krasta zone (Meco and Aliaj, 2000). At least, the Cukali zone is separated from the Krasta zone by thrusts (see Xhomo et al., 2002 for details).

A detailed discussion of all the aforementioned problems and the existing different models for this area is beyond the scope of the present contribution. The main topics of our study are the microfacies, micropalaeontology, biostratigraphy, and palaeogeographic position of the studied Upper Triassic to Lower Jurassic section and its possible connection to both the Budva Trough and the Cukali Trough in the area of the southern Albanian Alps zone north of Lake Shkodra (Fig. 1).

\section{GEOLOGICAL SETTING}

\section{Overview}

Vlahović et al. (2005) discuss the terms Dinaric Carbonate Platform, Adriatic-Dinaric Carbonate Platform (or Adriatic-Dinaridic Carbonate Platform) and Adriatic Carbonate Platform and recommended the term Adriatic

\footnotetext{
${ }^{1}$ University of Leoben, Department for Applied Geosciences and Geophysics: Petroleum Geology, Peter-Tunner-Str. 5, 8700 Leoben, Austria. 


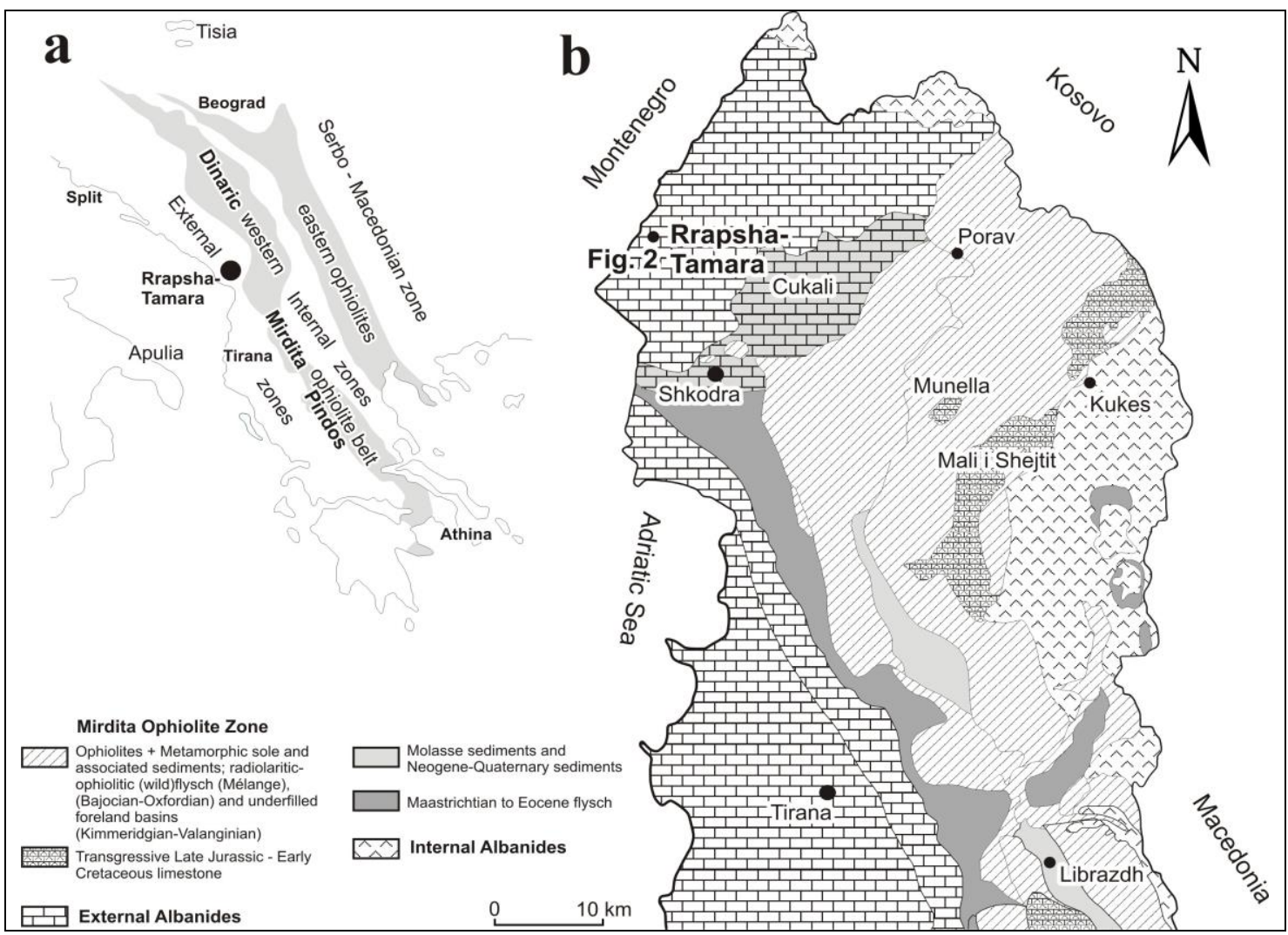

Fig. 1 Simplified tectonic map of Albania and studied locality (after Xhomo et al., 2002, Gawlick et al. 2008).

Carbonate Platform (AdCP) for the large Jurassic to Cretaceous shallow water carbonate platform striking from Slovenia to Albania and formed since the late Early Jurassic after a tectonic induced break-down. Our study area is located in the southeastern part of the Adriatic Carbonate Platform and belongs stratigraphically mainly to the youngest, third sequence of the AdCP basement (in the sense of Vlahović et al., 2005).

Following uniform Upper Triassic shallow-water lagoonal carbonates with megalodonts (equivalent to Dachstein Limestone; Meco and Aliaj, 2000) and peritidal dolomites on top the lower to middle part of the Lower Jurassic shallow-water limestones are widely distributed along the Adriatic Carbonate Platform: Northern Italy (Monaco, 2000; Fugagnoli, 2004: Calcari grigi), Slovenia (Buser and Debeljak, 1995; Ogorelec, 2011), Croatia (Kochansky-Devidé, 1957; Nikler and Sokač, 1968), SerbiaMontenegro (Radoičić, 1966) and Greece (VartisMatarangas et al., 1994) (Table 1). A specific limestone type is characterized by the mass occurrence of shells of lithiotids, a thick-shelled heterodont bivalves several centimetres in size belonging to several genera (e.g., Buser and Debeljak, 1996; Debeljak and Buser, 1998, Turnsek et al., 2003), developed during the Early Jurassic (Sinemurian, but especially abundant in Pliensbachian and Toarcian) (Flügel, 2004). All these occurrences display distinctive macro- and microscopically features as well as typical microfossil associations. Characteristic for the Tethyan realm, this lithofacies is also reported from the Iberian domain (Rey et al., 1990; Rey, 1993; Azeredo et al., 2003; Ruiz-Ortiz et al., 2004), and also from North America (Fraser et al., 2004).
The study area in north Albania (Fig. 1) belongs to the tectonic unit of the Albanian Alps zone (Meco and Aliaj, 2000, with references) and therein to the Malesia and Mahde subzone (Beccaluva et al., 1997). According to Meco and Aliaj (2000) the preserved stratigraphic sequence starts with Upper Triassic dolomites and lagoonal limestones with megalodonts. The Lower Jurassic should consist of dark grey biomicritic limestones with lithiotids followed by dolomites in the Middle to older Upper Jurassic. Therefore only few informations of the detailed stratigraphic evolution of the Early Jurassic are available from this area (Peza et al., 1973; see Meco and Aliaj, 2000). Our study is the first detailed stratigraphic investigation on the Upper Triassic to Lower Jurassic sedimentary succession in the Albanian Alps zone (Malesia and Madhde subzone) allowing a better correlation with the tectonic zones in the High Karst zone of the Outer Dinarides (for details see Vlahović et al. 2005) and extend the Lower Jurassic distribution map of important foraminifera taxa (Velić, 2007) to Albania.

\section{Studied section}

A continuous and conformable profile (thickness $~ 220$ m; Fig. 2) of Upper Triassic to the upper part of the Lower Jurassic neritic dark brownish-coloured dolomites and limestones was described in Albania for the first time by Schlagintweit et al. (2006). This Rrapsha-Tamara named section is cropping out along the mountainous road (Figs. 2 and 3) from Rrapsh-Starja (Rraphsa) to Tamarja (Peshtan), located north of Shkodra near Montenegro in the northwestern part of Albania (Albanian Alps zone, Fig. 1). 
Table 1. Distribution of lower to middle Lower Jurassic shallow-water limestones in the Dinaridic realm (examples).

\begin{tabular}{|c|c|c|}
\hline Locality & Reference & Microfacies - Microfossils \\
\hline $\begin{array}{l}\text { Rumija Mts., S-Serbia (Krajna), } \\
\text { close to the border of Albania }\end{array}$ & RADOIčić (1966) & $\begin{array}{c}\text { "Calcaire grumeleux", P. mediterraneus, } \\
\text { Orbitopsella, Thaumatoporella }\end{array}$ \\
\hline $\begin{array}{l}\text { Zetska Ravnica, S-Serbia, } \\
\text { close to the border of Albania }\end{array}$ & RADOIčić (1966) & $\begin{array}{l}\text { Calcaire á Lithiotis, P. mediterraneus, } \\
\text { O. praecursor, Pseudocyclammina sp. }\end{array}$ \\
\hline $\begin{array}{l}\text { District of Dubrovačko primorje - } \\
\text { Trebinje-Popovo polje, NNW of } \\
\text { Dubrovnik, S-Croatia }\end{array}$ & RADOIčić (1966) & $\begin{array}{l}\text { Calcaire á Lithiotis, Orbitopsella, } \\
\text { Lituosepta, P. mediterraneus, } \\
\text { Thaumatoporella }\end{array}$ \\
\hline $\begin{array}{l}\text { Region of Mosor-Biokovo-Baćine } \\
\text { S-Croatia }\end{array}$ & RADOIčić (1966) & $\begin{array}{l}\text { Calcaire á Lithiotis, Orbitopsella, } \\
\text { P. mediterraneus, Thaumatoporella }\end{array}$ \\
\hline $\begin{array}{l}\text { Region of Lemes NNW of Split, } \\
\text { Croatia }\end{array}$ & RADOIčić (1966) & $\begin{array}{c}\text { Calcaire á Lithiotis, O. praecursor, } \\
\text { P. mediterraneus }\end{array}$ \\
\hline $\begin{array}{l}\text { Region of Sošice SSW of Zagreb, } \\
\text { Croatia }\end{array}$ & RADOIčić (1966) & $\begin{array}{l}\text { "Calcaire organogene" à P. mediterraneus, } \\
\text { "Calcaire microgrumeleux" à L. recoarensis }\end{array}$ \\
\hline $\begin{array}{l}\text { Krka Valley between Zagradec } \\
\text { and Randol, Croatia }\end{array}$ & RADOIčić (1966) & $\begin{array}{c}\text { Calcaire á P. mediterraneus, Orbitopsella } \\
\text { praecursor, (strata with lithiotides) }\end{array}$ \\
\hline $\begin{array}{l}\text { Region of Plitvice, } \\
\text { Croatia }\end{array}$ & KoCHANSKY-DEVIDE (1958) & Orbitopsella praecursor \\
\hline $\begin{array}{l}\text { Region of Gorski Kotar, } \\
\text { Central Croatia }\end{array}$ & Gušıć \& VeLIć (1978) & $\begin{array}{c}\text { Association of Orbitopsella ssp., Lituosepta } \\
\text { recoarensis, Palaeodasycladus sp. }\end{array}$ \\
\hline $\begin{array}{l}\text { East of Gradac, Mt. Biokovo } \\
\text { S-Croatia }\end{array}$ & Gušlć (1977) & Limestones with Orbitopsella \\
\hline $\begin{array}{l}\text { Velebit Mountain, } \\
\text { Croatia }\end{array}$ & NIKLER \& SOKAč (1968) & $\begin{array}{l}\text { Fossiliferous imestones with Orbitopsella } \\
\text { and other microfossils }\end{array}$ \\
\hline
\end{tabular}

\section{RESULTS}

\section{Microfacies}

The succession starts with intertidal dolomites of Upper Triassic age (Fig. 4a) and is overlain by a more than 100 $\mathrm{m}$ thick series of peloidal, in parts laminated mudstones, wackestones, packstones to floatstones. Grainstones and shell layers occur occasionally. The upper part is Toarcian in age (Fig. 5). The microfacies of the exposed sequence (lamination, fenestral fabrics, internal breccias; Fig. 4 b,c) indicates peritidal to subtidal sedimentation in a restricted inter- to supratidal environment. A stacking of the succession in several peritidal parasequences, as described from the lower part of the Lower Jurassic of the Western Dinarides in Croatia (Bucković et al., 2001) seems possible, but is not directly evidenced, e.g. through bed-by-bed sampling. In addition, exact biostratigraphic age dating of this part of the succession is not possible due to the lack of stratigraphically relevant organisms. Therefore a correlation with other lower part of the Lower Jurassic successions is not possible.

The middle part of the section (Fig. 5) contains a diverse association of benthic foraminifera (Fig. 6) which according to Nikler and Sokač (1968) "qualifies the Middle Liassic the most fossiliferous Jurassic member". This part of the succession starts with oolithic packstones to grainstones (Fig. 4g). Higher up, in the middle and upper part of the succession lithiotid bivalves occur (Fig. 5; Fig. 6g) above dolomitic limestones on top of the oolithic packstones to grainstones. These lithiotid shells occur mainly as floatstones in a series of bioturbated mudstones and wackestones (Fig. 4d). They are generally considered to have been accumulated in the inner platform/lagoonal environments. Lithiotid-facies presence is presumably

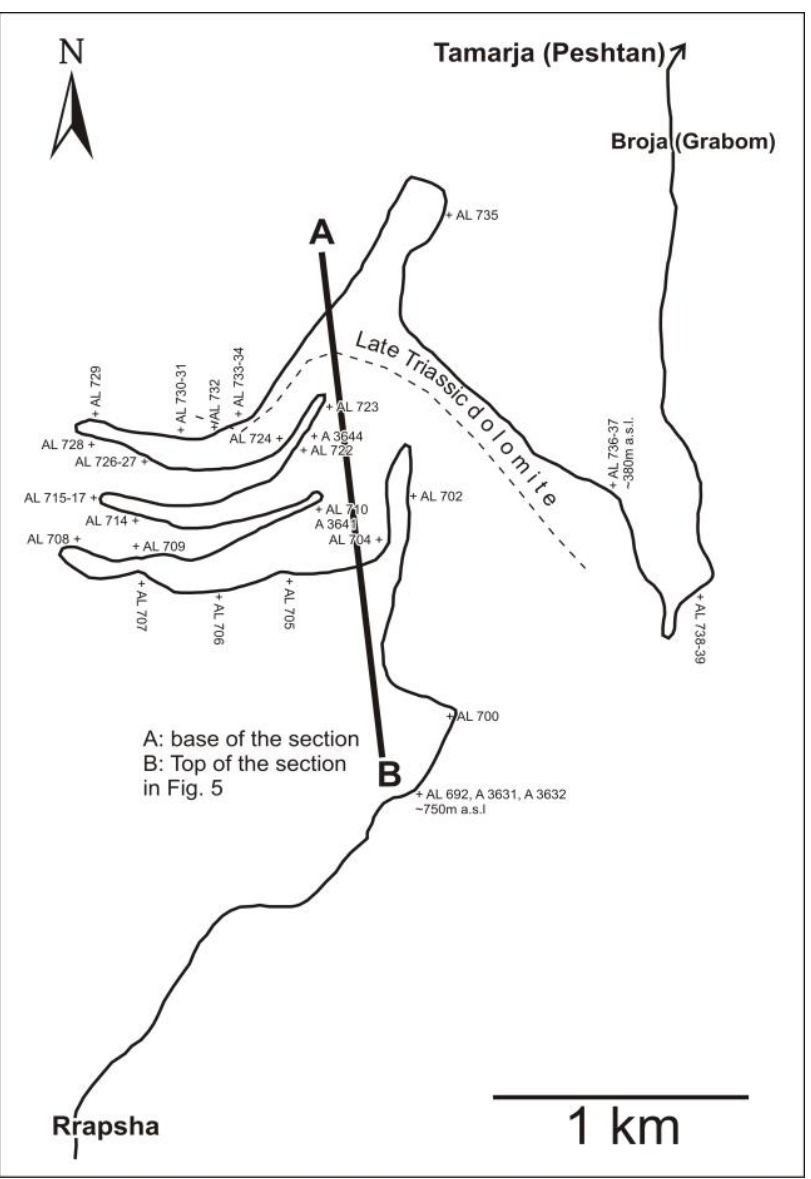

Fig. 2. Topographic map of the study area and locality of the Rrapsha-Tamara section. The thickness of the section A-B (approximately more than $220 \mathrm{~m}$ ) cannot be exactly measured in respect to covered parts of the section and some faults and is therefore calculated on base of the dipping and the altitude difference. The calculated thickness of nearly $300 \mathrm{~m}$ for the Lithiotid limestone by Krobicki et al. (2018) seems a bit too high. 

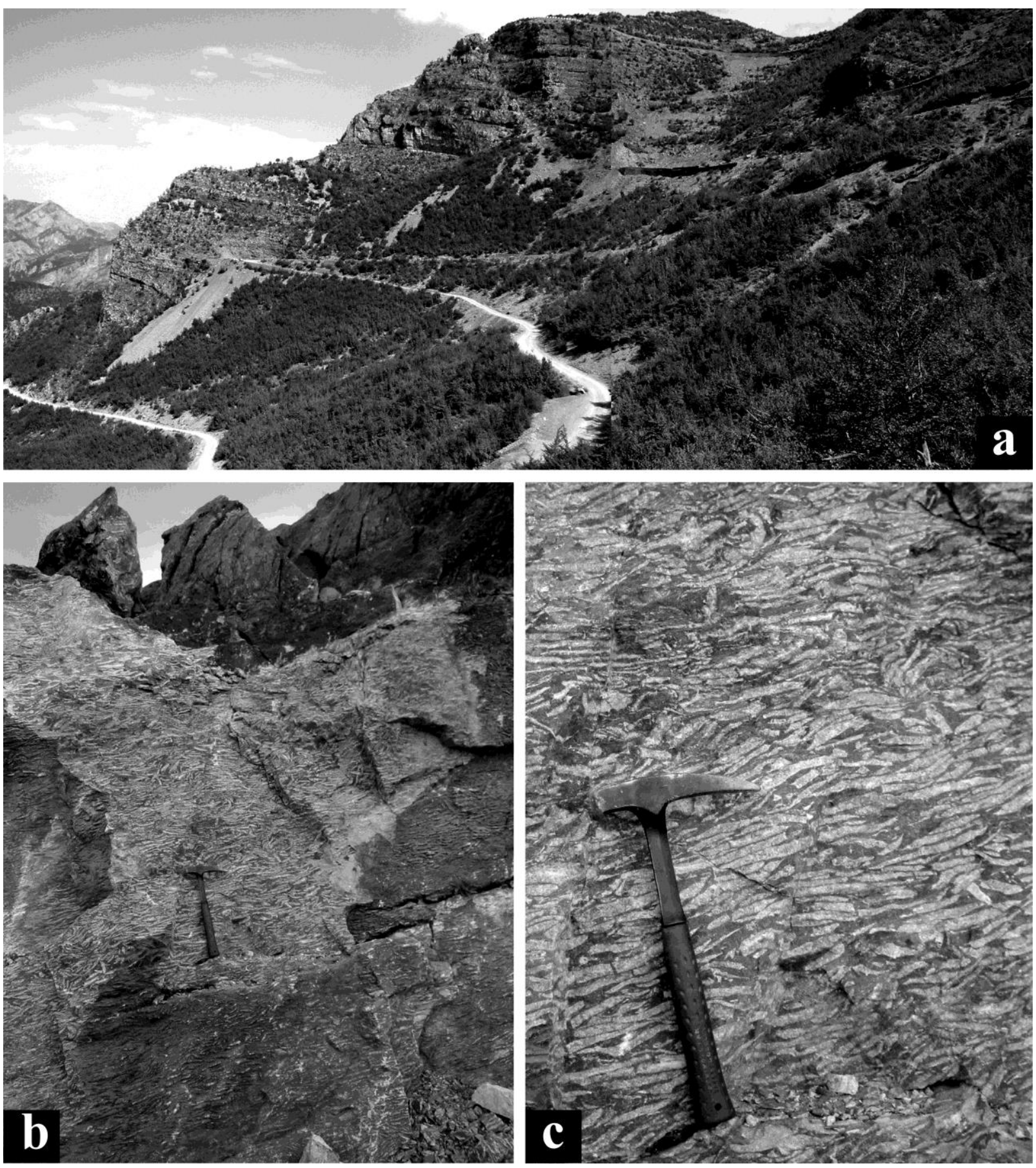

Fig. 3 Outcrop situation of the Late Triassic to Lower Jurassic Rrapsha-Tamara section. a Main section: view from the south. b Lithiotid limestones. c Enlarged part of the previous picture

also controlled by the occurrence of suitable low-energy, inner-platform environments (Debeljak and Buser, 1998; Ruiz-Ortiz et al., 2004 with references). Besides benthic foraminifera, we note the common presence of the incertae sedis Thaumatoporella parvovesiculifera (Raineri) and more rarely the dasycladalean alga Palaeodasycladus mediterraneus (Pia) (Fig. 6f). Above the first horizons with lithiotid bivalves again peloidal packstones (Fig. 4e) were deposited, while in some layers silification can be observed. The higher, most probably Toarcian part of the succession is characterized by several layers of lithiotid bivalves, in places in mass occurrences. In general floatstones and oncoidal rudstones to floatstones dominate (Fig. 4f,h). Tempestites occur occasionally. The topmost part of the succession consists of thick-bedded limestones with several-metres-thick horizons of lithiotid bivalves (Fig. 3c).

\section{Biostratigraphy}

Starting with Upper Triassic intensely recrystallized dolomites, the succession stratigraphically comprises the Lituosepta compressa (Fig. 5; Fig. 6e) and Orbitopsella lineage zones (Fig. 6a) of benthic foraminifera (Late Sinemurian to Pliensbachian in age) (e. g., Septfontaine, 1984; Fugagnoli and Broglio, 1996; Kabal and Tasli, 2003; Fugagnoli, 2004; Velić, 2007). The highest parts can be assigned to the Toarcian although it may not be 

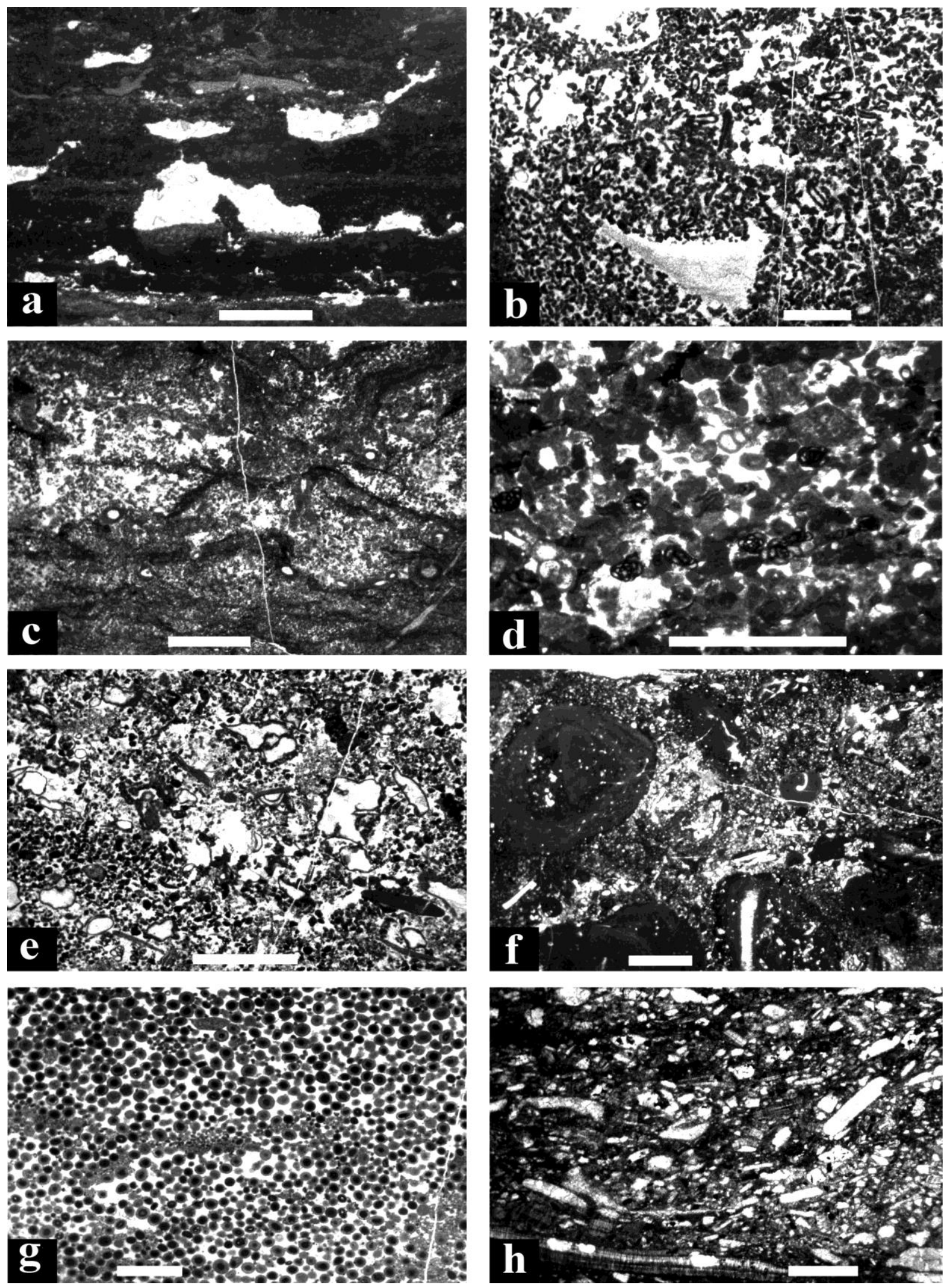

Fig. 4 Microfacies of Lower Jurassic limestones of the Rrapsha-Tamara section. a Stromatactis structures in laminated mudstones to fine-peloidal packstones with basal internal sediment and dolomite cement. Sample A-3649. Scale bar $=2 \mathrm{~mm}$. b Peloidal packstone with vugs and abundant tubes of Porferitubus lirimi Schlagintweit \& Gawlick. Sample AL-719. Scale bar $=1 \mathrm{~mm}$. c Wavy-laminated stromatolite ('cyanobacterial mats') with incorporated tubes of Porferitubus lirimi Schlagintweit \& Gawlick. Sample AL-726, scale bar $=2 \mathrm{~mm}$. d Peloid-foraminiferal packstone with abundant test of small miliolids, e.g. Planiinvoluta sp. Sample A-3644-u. Scale bar $=1 \mathrm{~mm}$. e Peloidal packstone with small benthic foraminifera and abundant Thaumatoporella parvovesiculifera (Raineri) of the morphotype "Messopotamella angulata" Dragastan et al. Sample A3644-0. Scale bar $=2 \mathrm{~mm}$. f Oncoidal packstone with fine bioclastic matrix. Sample AL-696. Scale bar $=2 \mathrm{~mm}$. g Ooid grainstone. Sample AL-716. Scale bar $=2 \mathrm{~mm}$. h Lithiotid debris limestone. Sample AL-697. Scale bar $=2 \mathrm{~mm}$. 


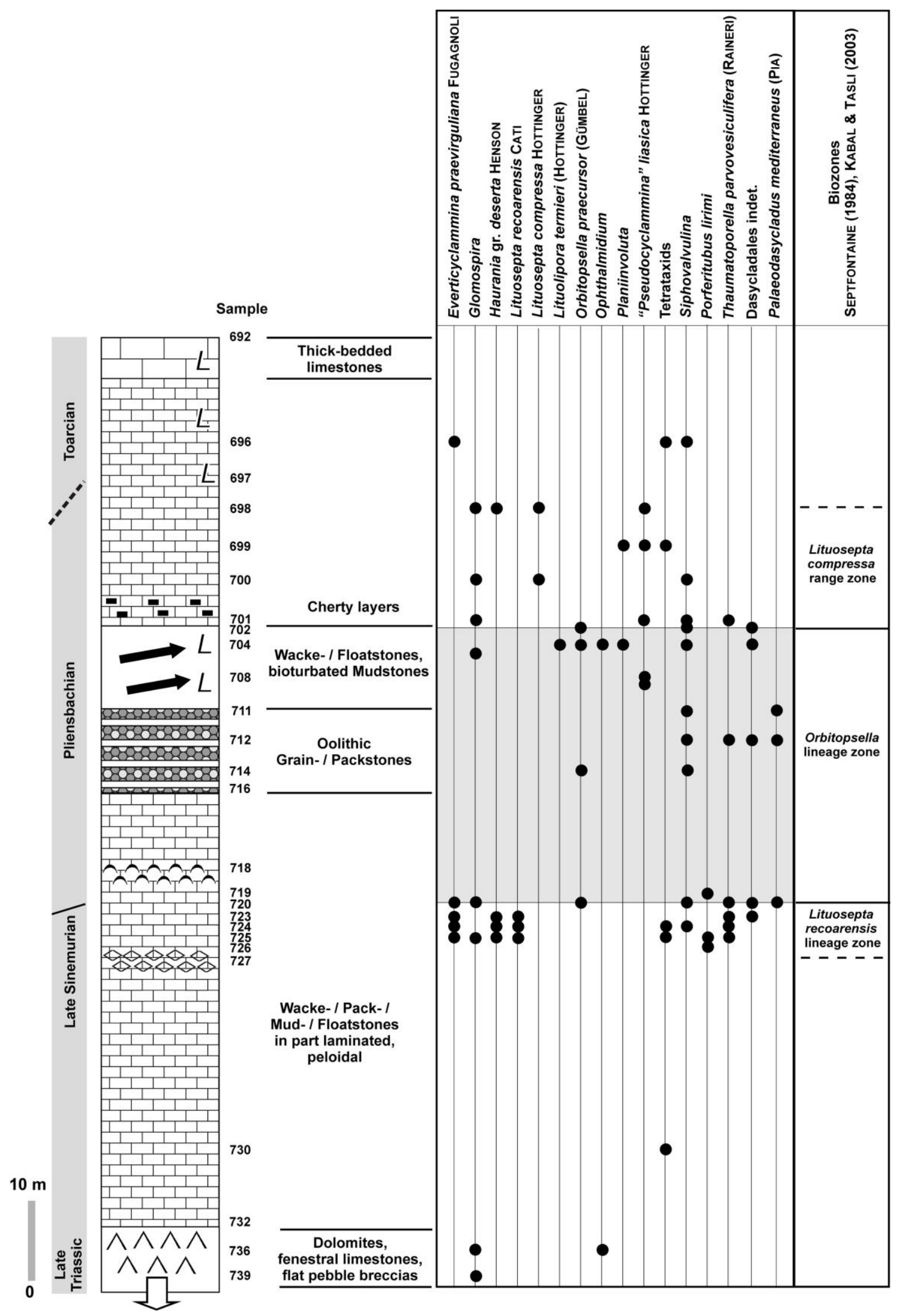

Fig. 5 Late Triassic to Lower Jurassic Rrapsha-Tamara section, Albania. Generalized lithology, micropalaeontological inventory and biostratigraphy. Legend: $L=$ Lithiotis shells. 

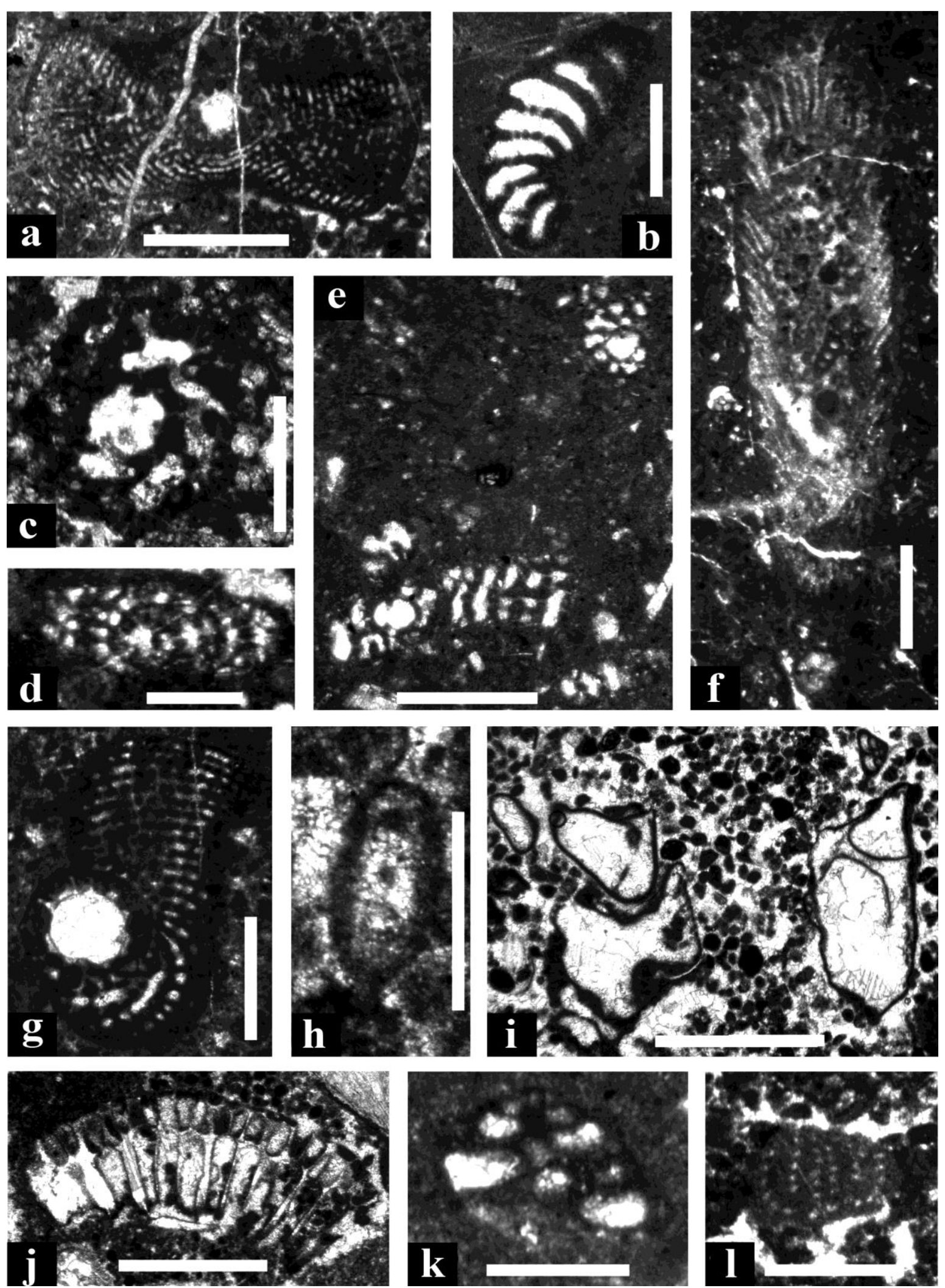

Fig. 6 Micropalaeontology of the Late Triassic-Lower Jurassic Rrapsha-Tamara section, Albania. a Orbitopsella praecursor (Gümbel). Sample AL-714. Scale bar $=1 \mathrm{~mm}$. b Lituolipora termieri (Hottinger). Sample AL-704. Scale bar $=0.5$ mm. c Everticyclammina praevirguliana Fugagnoli. Sample AL-696. Scale bar $=0.5 \mathrm{~mm}$. d "Pseudocyclammina" liasica Hottinger. Sample AL-701. Scale bar $=0.2 \mathrm{~mm}$. e Lituosepta recoarensis Hottinger. Sample AL-700. Scale bar $=0.5$ mm. f Palaeodasycladus mediterraneus (Pia). Sample AL-712. Scale bar $=1 \mathrm{~mm}$. g Orbitopsella praecursor (Gümbel). Sample AL-714. Scale bar $=0.5 \mathrm{~mm}$. h Involutina? sp. Sample AL-714. Scale bar $=0.5 \mathrm{~mm}$. i Irregular tube-shaped specimens (typus "Messopotamella angulata" Dragastan et al., 1985) of Thaumatoporella parvovesiculifera (Raineri), Sample A-3644-0. Scale bar $=1 \mathrm{~mm}$. j Fragment of Palaeodasycladus cf. mediterraneus (Pia). Sample A-3645-u. Scale $\mathrm{bar}=1 \mathrm{~mm}$. k Duotaxis metula Kristan. Sample AL-699. Scale bar $=0.2 \mathrm{~mm}$. I Parafavreina thoronetensis Brönnimann, Caron \& Zaninetti. Sample A-3648. Scale bar $=0.5 \mathrm{~mm}$. 
dated directly. The Pliensbachian/Toarcian boundary can tentatively be placed at the top of the Lituosepta compressa zone (see Fugagnoli, 2004) or slightly above (see Bassoullet, 1997). According to Bassoullet (1997) orbitopsellids and „Pseudocyclammina“ liasica should biostratigraphically not overlap in their ranges. In our samples there is a short interval in the Late Pliensbachian in which both species show an overlapping range. Further detailed investigations on shallow-water Pliensbachian sedimentary rocks may improve the age ranges of both species. The Triassic/Lower Jurassic (T/J) boundary cannot be fixed micropalaeontologically in the studied section. Also the lower part of the investigated profile ("Lower Liassic") is devoid of microfossils. Lithologically the $T / J$ boundary is marked by a sharp change from dolomites to a dominance of limestones presumably connected with a stratigraphic hiatus between both units triggered by a sea-level drop around the Triassic/Jurassic boundary. This is confirmed by a microbreccia horizon with reworked older clasts on top of the strongly recrystallized dolomites. In similar successions in Montenegro such dolomite was dated as Upper Triassic by the occurrence of some index fossils, e.g. Triasina hantkeni (Pajović et al., 2017).

It is worth mentioning that the stratigraphic occurrence of Lithiotid limestones ("Lithiotis" limestones) in the Dinaridic realm is not constant (Geyer, 1977). Whereas in Slovenia they occur in one distinct horizon ("lithiotid horizon", Pliensbachian, Buser and Debeljak, 1995), seven horizons within the middle part of the Lower Jurassic were reported from Croatia by Nikler and Sokač (1968) and Velić and Velić (2009). Partly in situ, most often, they occur as in the Rrapsha-Tamara section as debris limestones (Fig. 4), floatstones to bioclastic packstones. In situ "Lithiotis" build-ups (massive beds) with thicknesses of more than $10 \mathrm{~m}$ were reported from other parts of the Adriatic Carbonate Platform (e. g., Göhner, 1980) or Morocco (Scheibner and Reijmer, 1999).

\section{DISCUSSION}

As a result of our study we see a clear continuation of the Adriatic Carbonate Platform basement from the Dinarides to Albanides in the northern Albania, poorly investigated at the moment, helping to reconstruct the palaeogeography of the Adriatic Carbonate Platform (e. g., Vlahović et al., 2005). The Malesia and Madhe subzones of the Albanian Alps zone resemble perfectly the stratigraphic and facies evolution of the High Karst zone of the Outer Dinarides.

A temporary, short-lasting drowning of the shallowmarine carbonate platform area in latest Pliensbachian or Toarcian, as described in several parts of the "Lithiotis" platform (e. g., Buser and Debeljak, 1995; Ruiz-Ortiz, 2004; Vlahović et al., 2005; Sabatino et al., 2013) and even locally forming of the new hemipelagic basins (e.g., the Jurassic Budva Trough - Goričan, 1994), is not visible in the studied section. Instead, we clearly see a continuation of mainly shallow-water conditions from the Sinemurian/Pliensbachian to the Toarcian and therefore a clear continuation of the High Karst zone of the Dinarides to the western part of the Albanian Alps zone. Intercalated thin coal horizons (Krobicki et al., 2018) confirm this 10 view. Only the thin cherty layers with relics of spicules in the upper part of the section (Lituosepta compressa range zone) may indicate a short flooding event within the shallow-water area, rapidly followed again by lithiotid debris limestones. Lithiotid limestones occur in the Albanian Alps zone not in a distinct stratigraphic horizon as in several other localities of the Adriatic Carbonate platform. We prove several independent layers in the Pliensbachian and Toarcian.

We see no possibility to connect the Budva Trough with the Cukali Trough by a hemipelagic corridor in the Late Triassic to late Early Jurassic through the Albanian Alps zone. But the need for further detailed stratigraphic and facies investigations in all neighbouring regions (Budva zone, Albanian Alps zone, Cukali zone), on the whole Triassic to Jurassic sequence is clearly evident to find arguments for a possible connection between the Budva and Cukali area. Especially the existing confusion about the correlation of the different tectonic units and their tectonostratigraphic evolution needs clear definitions on the basis of exact stratigraphic and facies data.

\section{ACKNOWLEDGEMENTS}

The joint project „Tectonothermal Evolution of Albanides 2003-2005" received financial support from the Albanian Government (Geological Survey of Albania), University of Leoben, University of Vienna, Austrian Academic Exchange Service, Austria and University of Tübingen, Germany. Thanks to Sigrid Missoni (Austria), Richard Lein (Austria), Lirim Hoxha (Albania), and Stak Vukaj (Albania) for field assistance, discussions and providing samples. Careful reviews of Igor Vlahović and Ivo Velić are gratefully acknowledged.

\section{REFERENCES}

Azeredo, A.C., Manuppella, G., Ramalho, M.M., 2003. The Late Sinemurian carbonate platform and microfossils with Tethyan affinities of the Algarve Basin (South Portugal). Facies, 48: 49-60.

Bassoullet, J.-P., 1997. Les Grands foraminifères. In: Cariou, E., Hantzpergue, P. (coord.), Biostratigraphie du Jurassique ouest-européen et Méditerranéen: zonations paralléles et distribution et microfossiles. Bulletin des Centres de Recherches ExplorationProduction Elf- Aquitaine Mémoire, 17, 293304.

Beccaluva, L., Shallo, M., Coltori, M., Premti, I., Sienna, F., 1997. Albania. In: Moores, E.M., Fairbridge, R.W. (eds.), Encyclopedia of Europaean and Asian Regional Geology, 6-16, Chapman \& Hall.

Bucković, D., Jelaska, V., Cvetko Tešović, B., 2001. Facies variability in Lower Liassic carbonate successions of the Western Dinarides (Croatia). Facies, 44: $151-161$.

Buser, S., Debeljak, I., 1995. Lower Jurassic beds with bivalves in south Slovenia. Geologija, 37-38: 23-62.

Črne, A.E., Buser, S., 2006. The Adriatic-Dinaric Carbonate Platform margin in the Liassic: a comparison between successions in Slovenia and Montenegro. In: Parente, M. (ed.), Geology and Paleontology of the 
Peri-Adriatic Area - A tribute to Rajka Radoičić, 5-6 May 2006, Napoli, Sci. Progr. \& Abstracts, 12-13.

Črne, A., Goričan, S., 2008. The Dinaric Carbonate Platform margin in the Early Jurassic: a comparison between successions in Slovenia and Montenegro. Italian Journal Geosciences (Boll.Soc.Geol. It.), 127: 389-405.

Buser, S., Debeljak, I., 1996. Lower Jurassic beds with bivalves in south Slovenia. Geologija, 37/38, 23-62.

Debeljak, I., Buser, S., 1998. Lithiotid Bivalves in Slovenia and Their Mode of Life. Geologija, 40, 11-64.

Dimitrijević, M., 1997. Geology of Yugoslavia. Geological Institute Gemini Spec. Publ., 187 p.

Dragastan, O., Papanikos, D. \& Papanikos, P., 1985. Foraminifères, algues et microproblematica du Trias de Messopotamos, Épire (Grèce continentale). Revue de Micropaléontologie, 27 (4): 244-248.

Flügel, E., 2004. Microfacies of Carbonate Rocks: Analysis, Interpretation and Application. Springer, Berlin, $976 \mathrm{p}$.

Fraser, N.M., Bottjer, D.J., Fischer, A.G., 2004. Dissecting ,Lithiotis“ bivalves: Implications for the Early Jurassic reef eclipse. Palaios, 19: 51-67.

Fugagnoli, A., 2004. Trophic regimes of benthic foraminiferal assemblages in Lower Jurassic shallow water carbonates from northeastern Italy (Calcari Grigi, Trento Platform, Venetian Prealps). Palaeogeography, Palaeoclimatology, Palaeoecology, 205: 111130.

Fugagnoli, A., Broglio, C.L., 1996. Revised biostratigraphy of Lower Jurassic shallow water carbonates from the Venetian Prealps (Calcari Grigi, Trento platform, Northern Italy). Studi Trentini di Scienze Naturali Acta Geologica, 73 (1996): 35-73.

Gawlick, H.-J, Frisch, W., Hoxha, L., Dumitrica, P. Krystyn, L., Lein, R., Missoni, S., Schlagintweit, F., 2008. Mirdita Zone ophiolites and associated sediments in Albania reveal Neotethys Ocean origin. International Journal of Earth Sciences, 92: 865-881.

Geyer, O.F., 1977. Die „Lithiotis-Kalke“ im Bereich der unterjurassischen Tethys. Neues Jahrbuch für Geologie und Paläontologie Abhandlungen, 153 (3): 304-340.

Göhner, D., 1980. "Covel dell'Angiolono" - ein mittelliassisches Lithiotis-Schlammbioherm auf der Hochebene von Lavarone (Provinz Trento, Norditalien). Neues Jahrbuch für Geologie und Paläontologie Monatshefte, 10: 600-619.

Goričan, S., 1994. Jurassic to Cretaceous radiolarian biostratigraphy and sedimentary evolution of the Budva Zone (Dinarides, Montenegro). Mémoires de Géologie, 18: 1-177.

Gušić, I., 1977. A new foraminiferal family, Biokovinidae, from the Jurassic of the Dinarides and its phylogenetic relationships. Palaeontologia Jugoslavica, 18: 7-31.

Gušić, I. Velić, I., 1978. Lituolipora polymorpha n. gen., n. sp (Foraminiferida, Lituolacea?) from the Middle Liassic of the Outer Dinarids in Croatia and the establishment of the Outer Dinarids in Croatia and the establishment of a new family, Lituoliporidae. Geološki vjesnik, 30 (1): 73-93.
Kabal, Y., Tasli, K., 2003. Biostratigraphy of the Lower Jurassic carbonates from the Aydincik Area (Central Taurides, S. Turkey) and morphological analysis of Lituolipora termieri (Hottinger, 1967). Journal of Foraminiferal Research, 33 (4): 338-351.

Kochansky-Devidé, V. (1957): Generationswechsel der Orbitopsella praecursor im Lias von Plitvice (Kroatien). Geol. vjesnik, XI: 84-86.

Kochansky-Devidé, V., 1958. Neue Fundorte der Foraminifere Orbitopsella praecursor im Lias von Jugoslawien. Bulletin Sci. Yougoslavia, 4 (2): 44-45.

Krobicki, M., Iwanczuk, J., Barbacka, M., Muceku, B., 2018. Early Jurassic (Pliensbachian-Early Toarcian) shallow-water environments with faunal and floral associations in the Albanian Alps. Geologica Balcanica, XXI International Congress of the Carpathian Balkan Geological Association (CBGA) 10.-13.Sept. 2018, Neubauer, F., Brendel, U., Friedl, G. (Eds.), Advances of Geology in southeast European mountain belts, 52, Bulgarian Academy of Sciences.

Meco, S., Aliaj, S., 2000. Geology of Albania. Beiträge zur regionalen Geologie der Erde, 28, 1-246.

Monaco, P., 2000. Biological and physical agents of shell concentrations of Lithiotis facies enhanced by microstratigraphy and taphonomy, Early Jurassic, Trento Area (Northern Italy). GeoResearch Forum, 6, 473486.

Nikler, L., Sokač, B., 1968. Biostratigraphy of the Jurassic of Velebit (Croatia). Geološki vjesnik, 21, 161176.

Nopsca, F., 1929. Geologie und Geographie Nordalbaniens mit Anhang von H.V. Mzik. Beiträge zur Kartographie Albaniens nach orientalischen Quellen. Geologica Hungarica, 3: 1-704.

Ogorelec, B., 2011. Microfacies of Mesozoic carbonate rocks of Slovenia. Geologija, 54 (2), 1-136.

Pajović, M., Mirković, M., Svrkota, R., Ilić, D., Radusinović, S., 2017. Geologija Boksitonosnog Rejona Vojnik-Maganik (Crna Gora). Separate issues of the Geological Bulletin of the Geological Survey of Montenegro, 21, $431 \mathrm{p}$.

Petković, K., 1958. Neue Erkenntnisse über der Bau der Dinariden. Jahrbuch der Geologischen Bundesanstalt, 101: 1-24.

Peza, L.H., Xhomo, A. \& Theodori, P. (1973): Stratigrafia e depozitimeve mesozoike te zones se Alpeve Shqiptare. - Archives ISPGJ, 1-235, Tirane.

Radoičić, R., 1966. Microfaciès du Jurassique des Dinarides externs de la Yougoslavie. Geologija, 9, 1-377.

Rey, J., 1993. Analisis de la Cuenca Subbetica durante el Jurassico y el Cretacico en la transversal Caravaca Valez-Rubio. Thesis Doctoral Universidad de Granada, Facultad de Ciencias, 460 p.

Rey, J., Andreo, B., García-Hernández, M., Martín Algarra, A., Vera, J., 1990. The Liassic "Lithiotis" facies north of Vélez-Rubio (Subbetic zone). Revista Sociedad Geológico España, 3, 199-212.

Robertson, A., Shallo, M., 2000. Mesozoic-Tertiary tectonic evolution of Albania in its regional Eastern Mediterranean context. Tectonophysics, 316, 197254.

Ruiz-Ortiz, P.A., Bosence, D.W.J., Rey, J., Nieto, L.M., Castro, J.M., Molina, J.M., 2004. Tectonic control of 
facies architecture, sequence stratigraphy and drowning of a Liassic carbonate platform (Betic Cordillera, Southern Spain). Basin Research, 16, 235-257.

Sabatino, N., Vlahović, I., Jenkyns, H.C., Scopelliti, G., Neri, R., Velić, I., Prtoljan. B., 2013. Carbon-isotope record and palaeoenvironmental changes during the early Toarcian Oceanic Anoxic Event in shallowmarine carbonates of the Adriatic Carbonate Platform in Croatia. Geological Magazine, 150/6, 1085-1102.

Schlagintweit, F., Gawlick, H.-J., Missoni, S., Lein, R., Vukaj, S., Hoxha, L., 2006. Triassic to Early Jurassic shallow water carbonates from the Skodra area (NW Albania) - a part of the Adriatic-Dinaric Carbonate Platform. In: Sudar, M., Ercegovac, M., Grubić, A. (eds.), Proceedings XVIIIth Congress of CarpathianBalkan Geological Association, 531-534, (National committee of the Carpathian - Balkan Geological Association; Serbian Geological Society).

Scheibner, C., Reijmer, J.J.G., 1999. Facies patterns within a Lower Jurassic upper slope to inner platform transect (Jberl Bou Dahar, Morocco. Facies, 41, 5580.

Septfontaine, M., 1984. Biozonation (á 1' aide des foraminifèrs imperforés) de la plate-forme interne carbonate liasique du Haut Atlas (Maroc). Revue de Micropaléontologie, 27 (3), 209-229.

Tari, V., 2002. Evolution of the northern and western Dinarides: a tectonostratigraphic approach. EGU
Stephan Mueller Special Publication Series, 1, 223236.

Turnsek, D., Buser, S., Debeljak, I., 2003. Liassic coral patch reef above the "Lithiotid limestone" on Trnovski gozd plateau, west Slovenia. Razprave IV. Razreda SAZU, 44 (1), 285-331.

Vartis-Matarangas, M., Zambetakis-Lekkas, A., Matarangas, D., 1994. Microfacies and sedimentary conditions of Liassic Parnassos carbonate platform (Distomo area). Bulletin of the Geological Society of Greece, 30 (2), 187-199 (in Greek).

Velić, I., 2007. Stratigraphy and Palaeobiogeography of Mesozoic Benthic Foraminifera of the Karst Dinarides (SE Europe). Geologia Croatica, 60 (1), 1-113.

Velić, I., Velić, J., 2009. Geological guide through National park Northern Velebit. National park Northern Velebit Krasno, 143 p. (in Croatian).

Vlahović; I., Tišljar, J., Velić, I., Matičec, D., 2005. Evolution of the Adriatic Carbonate Platform: Palaeogeography, main events and depositional dynamics. Palaeogeography, Palaeoclimatology., Palaeoecology, 220, 333-360.

Xhomo, A., Kodra, A., Dimo, L., et. al., 2002: Geological Map of Albania 1:200000 scale. - Geological Survey of Albania, Republika e Shqiperise. 